\title{
Factors affecting feelings of justice in biodiversity conflicts: towards fairer jaguar management in Calakmul, Mexico
}

\author{
Lou Lecuyer, Sophie Calmé, F. Guillaume Blanchet, Birgit Schmook, \\ and Rehema M. White
}

\begin{tabular}{|c|c|}
\hline Date of deposit & 14082019 \\
\hline Document version & Author's accepted manuscript \\
\hline Access rights & $\begin{array}{l}\text { Copyright (c) } 2019 \text { Elsevier Ltd. All rights reserved. This work is } \\
\text { made available online in accordance with the publisher's policies. } \\
\text { This is the author created, accepted version manuscript following } \\
\text { peer review and may differ slightly from the final published } \\
\text { version. }\end{array}$ \\
\hline $\begin{array}{l}\text { Citation for } \\
\text { published version }\end{array}$ & $\begin{array}{l}\text { Lecuyer, L., Calmé, S., Blanchet, F. G., Schmook, B., \& White, R. } \\
\text { M. (2019). Factors affecting feelings of justice in biodiversity } \\
\text { conflicts: towards fairer jaguar management in Calakmul, Mexico. } \\
\text { Biological Conservation, 237, 133-144. }\end{array}$ \\
\hline $\begin{array}{l}\text { Link to published } \\
\text { version }\end{array}$ & https://doi.org/10.1016/j.biocon.2019.06.017 \\
\hline
\end{tabular}

Full metadata for this item is available in St Andrews Research

Repository at: https://research-repository.st-andrews.ac.uk/

\section{St Andrews Research Repository}


1 Factors affecting feelings of justice in biodiversity conflicts: towards fairer jaguar

2 management in Calakmul, Mexico

4 Abstract

5 Conservation focuses on environmental objectives, but neglecting social concerns can lead to

6 a feeling of injustice among some actors and thus jeopardise conservation aims. Through a

7 case study on a biodiversity conflict around jaguar management in the Calakmul region of

8 Mexico, we explored actors' feelings of injustice and their associated determinants. We

9 employed a novel framework distinguishing four dimensions of justice: recognition,

10 ecological, distributive and procedural. By conducting and analysing 235 interviews with

11 farmers and ranchers, we investigated what might drive their feeling of injustice, namely their

12 perceptions of the injustice itself (i.e. location, intentionality, stability), individual

13 characteristics (i.e. socio-economic status, motivation, environmental identity), and

14 interactions with their environment (i.e. natural and social). We also asked the participants to

15 choose one statement for each of the 10 pairs of statements that we presented to them, from

1618 statements that characterized their feeling of justice toward jaguar management based on

17 different criteria. Using a pioneering statistical analysis, BTLLasso, we showed the

18 complexity of the drivers of feeling of justice. Self-interest assumptions were not upheld;

19 feelings of fairness were only weakly influenced by experience of jaguar attacks. Feelings of

20 justice were influenced mainly by factors related to actors' intra-and inter-group relationships

21 (e.g. perception of collective responsibility, coherence perceived in the group to which they

22 identified). Our analyses also allowed us to compare the effects of different factors on the

23 assessment of criteria by diverse actors. For example, it revealed that differences in the

24 organisations and groups perceived as being responsible for jaguar management modify a

25 participant's perception of fairness. This nuanced understanding of how people build their 
perception of justice can inform practitioners who seek fairer and more effective conservation approaches. Whilst details will be context specific, it emerged that supporting relationship building and enabling debate over ecological responsibilities are important and conservation efforts should go beyond merely offering financial compensation for livestock depredation. We conclude that perception of justice is a neglected but important aspect to include in integrative approaches to managing biodiversity conflicts, and that novel mixed methods can advance both conceptual and applied understanding in this area.

Keyword: fairness, paired comparison, Bradley-Terry-Luce Lasso, self-interest motivation, group identity.

\section{Introduction}

The conservation of large charismatic species can involve biodiversity conflicts in which disagreements between actors must be addressed (Redpath et al., 2013; White et al., 2009).

Biodiversity conflicts are driven partly by competing visions of fairness (Müller, 2011; Redpath et al., 2013), and feeling of justice can be a good predictor of people's attitudes and behaviours regarding conservation (Martin et al., 2014; Sikor et al., 2014) ${ }^{1}$. Someone perceiving a lack of fairness might resist conservation rules (Dawson et al., 2017) or limit their endorsement of pro-environmental action (Kals and Russell, 2001). Perceived unfairness can result also in profound resentment and social conflict (Schlosberg, 2007). Conversely, positive feelings of justice increase trust in decision-makers (Lauber, 1999), acceptance of decisions by locals (Davenport et al., 2007), overall effectiveness of conservation actions (Oldekop et al., 2016), and reduce conflict (Lind and Tyler, 1988). Consequently, research

\footnotetext{
${ }^{1}$ Fairness and feeling of justice here are both used as synonym to talk about subjective justice.
} 
focusing on, and policies supporting, the incorporation of justice into environmental issues has been increasing, especially issues related to climate change (Agyeman et al., 2016), payments for ecosystem services (Martin et al., 2014), protected area management (Dawson et al., 2017), and large carnivore conservation (Bredin et al., 2018; Jacobsen and Linnell, 2016). In this study, we adopted a justice approach to jaguar management around the Calakmul Biosphere Reserve, Mexico. Specifically, we used an empirical approach to identify factors affecting the feeling of justice in local farmers and ranchers. In doing so, we offer new insights for theoretical considerations of justice while proposing practical steps to manage biodiversity conflicts.

Feelings of justice represent actors' positions on particular issues, at a specific time and in a particular context (Martin et al., 2014; Schlosberg, 2007; Sikor et al., 2014). Those feelings are based on a plurality of views of justice that calls for an approach encompassing several dimensions of justice. We used a framework that accounts for four dimensions of justice: distributive justice (fair distribution of the costs and benefits of conservation), procedural justice (fair decision-making process), ecological justice (fair treatment of the natural world), and justice-as-recognition (fair integration of group identity, lifestyle, knowledge and viewpoints) (Lecuyer et al., 2018). While recent studies have often proposed frameworks where justice-as-recognition includes ecological justice (e.g., Jacobsen and Linnell, 2016; Martin et al., 2016; Schlosberg, 2007), we have previously shown that ecological justice can be a distinct dimension that may be addressed differently from justiceas-recognition (Lecuyer et al., 2018). These four dimensions of justice enabled us to broadly frame local actors' perception of justice and to explore variability among the dimensions. Divergent viewpoints on fairness may be a major obstacle for mutual understanding (Müller, 2011), the latter being necessary to manage biodiversity conflicts effectively. It is thus important to test empirically how the factors influencing feelings of justice vary among 
individuals. The issue itself (characteristics of the conflict i.e. location, intentionality, stability), the individual (i.e. socio-economic status, motivation, environmental identity), and the context (i.e. natural and social) can all influence one's feelings of justice (see Table 1 for more complete definitions and references). People might perceive the dimensions of justice differently and employ different criteria to explain their perception of it (e.g. Lauber, 1999; Martin et al., 2014; Zafra-Calvo et al., 2017). In the example of jaguar management, perception of distributive justice might depend, for instance, on socio-economic status or previous experience of jaguar attack. Researchers have disputed the motives driving people's desire for fairness, some attributing them to self-interest and others to group identity (Lind and Tyler, 1988; Skitka et al., 2010). The self-interest assumption implies that people's main motivation is to maximize their reward (Skitka et al., 2010). The group identity assumption proposes that relationships within and between groups are potent determinants of fairness judgments (Lind and Tyler, 1988; Skitka et al., 2010). According to their own subjective judgment, individuals could thus adopt different criteria to achieve perceived justice. In this paper, we employed a novel mode of analysis that uses a mixed-method approach to achieve a comprehensive analysis of all justice dimensions. We propose a systematic and quantitative investigation of the determinants of feelings of justice that accounts for the multi-dimensional facets of justice and its perception. Research on the plurality of, and individual variation in, justice perception has been qualitative in many cases (Coolsaet, 2016; Martin et al., 2014; Smith and McDonough, 2001; but see Zafra-Calvo et al., 2017), while studies using a quantitative approach have often focused on a single dimension of justice, usually procedural justice (e.g. Lauber, 1999). Here, we used an enhanced version of the Bradley-Terry model (Schauberger and Tutz, 2017) to develop interdisciplinary enquiry around the concept of justice and to inform future research using quantitative methods in combination with qualitative data to reveal patterns of feelings of justice. 
101 jaguar management around the Calakmul Biosphere Reserve in Mexico. We investigated the

102 jaguar conflict in Calakmul to examine factors influencing feelings of justice within a

103 theoretical framing of multiple dimensions of justice. This study complements the work of

104 Lecuyer et al. (2018), which used qualitative data to explain how feelings of injustice in local

105 communities surrounding jaguar management in Calakmul are constructed. Here, we aimed to

106 (1) identify factors influencing local actors' perceptions of justice; (2) assess how the criteria

107 that local actors used to describe their feelings of justice cluster; (3) offer practical advice on

108 strategies to achieve 'justice' and support 'fair' management actions; and (4) present a novel

109 methodology for the analysis of empirical data on local perceptions of justice. We thus

110 contribute to theorization in this area, but also offer practical recommendations for

111 biodiversity conflict management. By helping to develop mutual understanding and foster an

112 open dialogue among actors, our research facilitates fair and effective conservation action.

113

114

115

116 
Table 1. External factors of justice extracted from the literature and arranged according to whether they depend on the resources or injustice considered, on the individual, or on the context in which the situation takes place.

\begin{tabular}{lll}
\hline $\begin{array}{l}\text { Category of } \\
\text { external factor }\end{array}$ & External factor & Definition
\end{tabular}

\section{Related to the} injustice itself

Responsibility

Who/what is held responsible for the injustice: an individual, an organization or intangible factors

Intentionality

Whether the injustice is caused voluntarily or not by one (or more) actors.

Duration

Related to the individual

Individual
characteristics

Motivation

Environmental identity

Related to contextual factors

\begin{abstract}
Physical environment
\end{abstract}

Intra-group relationships

Inter-group relationships
Whether the injustice and its cause(s) are temporary or long lasting.

Socio-economic and demographic attributes, and previous experience of the actors.

The actors' objectives and expectations regarding the situation.

Whether and how the environment plays an important part in someone's identity.

The physical environment influences how an actor perceives place identity and connects to the natural world.

Observation of others' behaviour in the group is used to interpret if one's behaviour is appropriate in a given situation. Social norms to which members of a social group state adherence are likely

Perception of the legitimacy of an external group that promotes a certain behaviour. Such legitimacy influences how people act in accordance with each other and supports a legitimated norm or set of behaviours. to strongly benefit or legitimize that group.
Ohl et al., 2008; Utne and Kidd, 1980

Della Fave, 1986; Ohl et al., 2008; Utne and Kidd, 1980

Ohl et al., 2008; Utne and Kidd, 1980

Clayton and Opotow, 2003; Kellerhals et al., 1997

Parris et al., 2014

Clayton et al., 2016; Clayton and Opotow, 2003; Müller, 2011; Parris et al., 2014; Stets and Biga, 2003

Agyeman et al., 2016;

Marques et al., 2015;

Parris et al., 2014

Clayton et al., 2016; Clayton and Opotow, 2003; Colvin et al., 2015; Lute and Gore, 2014; Marques et al., 2015; Parris et al., 2014

Clayton et al., 2016; Clayton and Opotow, 2003; Colvin et al., 2015; Lauber, 1999; Lute and Gore, 2014; Parris et al., 2014; 
355 2.1. Species of interest and study area

356 As a top predator and flagship species, the jaguar is a focal species for environmental

357 protection and biodiversity conservation (Sanderson et al., 2002). However, it also represents 358 a threat to livelihoods because of livestock depredation (Zarco-González et al., 2013). This

359 has resulted in hunting and poisoning of jaguars, representing a significant threat to the 360 survival of certain jaguar populations (Inskip and Zimmermann, 2009). In Mexico, the jaguar 361 is considered an endangered species (SEMARNAT, 2010). Recent studies showed that the

362 Yucatán peninsula, especially the region encompassing the Calakmul Biosphere Reserve and 363 its surroundings, hosts one of the largest continuous areas highly suitable for jaguars

364 (Rodríguez-Soto et al., 2011).

The Calakmul region broadly corresponds to the municipality of the same name,

366 which covers almost $14,000 \mathrm{~km} 2$, half of which corresponds to the Calakmul Biosphere

367 Reserve. The municipality is home to 28,424 people, living in 62 ejidos distributed around the 368 reserve (INEGI, 2015). An ejido is a land tenure system often combining both individual and 369 communal land rights and in which decisions affecting ejido life are taken collectively among 370 the ejidatarios, the land-tenure right holders (Warman and Warman, 2001). A large influx of 371 people arrived in the Calakmul region between the 1970's and the mid 1990's, mainly from 372 the Gulf coast and central regions of Mexico. In this region, people engage in a wide range of 373 natural resource-based activities, including honey production and logging, although most 374 depend on subsistence maize agriculture (Turner et al., 2004). In addition, many families in 375 the region own livestock, mostly cattle and sheep. Government programmes have sponsored 376 sheep production, hence there has been a recent increase in families owning small flocks of 377 sheep to provide additional income (Schmook and Radel, 2008). 
The co-occurrence of livestock and jaguars and pumas makes Calakmul a high-risk

379 zone for large cats' attacks on livestock. Marshall et al. (under review) found that over 30\% of 380 the ranchers suffered at least one attack between 2013 and 2015 in the Calakmul region, two381 thirds of which they attributed to jaguar. Widespread large cats' depredation affects mostly 382 sheep owners, partly because of livestock husbandry practices (Lecuyer et al., unpubl. data).

383 To compensate for economic losses from predators, a national compensation scheme was 384 created in the late 2000's. The scheme is funded through the National Confederation of 385 Livestock Organizations (Confederación Nacional de Organizaciones Ganaderas), and is 386 accessible to any livestock rancher who can provide evidence of ownership, without any 387 insurance cost to the claimant. Furthermore, the Reserve and a local non-governmental 388 organization (PRONATURA) have been helping local ranchers to complete and submit the 389 required report after an attack. The Reserve also plays a role in jaguar management through 390 biological monitoring, including monitoring undertaken by local groups trained by the 391 Reserve. Additionally, the Reserve sporadically delivers technical and financial support to 392 communities to implement mitigation measures, like electric fences, to limit the risk of attack. 393 PRONATURA has been providing camera traps to ranchers to identify the predator in case of 394 an attack; PRONATURA also carried out an awareness campaign, and was involved in 395 multiple events regarding jaguar conservation (pers. obs). Despite these efforts, jaguar 396 management is causing a latent and, at times, intense biodiversity conflict among the region's 397 actors, leading to feelings of injustice in local populations (Lecuyer et al., 2018).

\subsection{Data collection}

400 We conducted interviews in 45 ejidos located in the Calakmul region with both ranchers (i.e. 401 people primarily practising livestock production) and farmers (i.e. people primarily practising 402 agriculture and not owning livestock). We proposed that ranchers might perceive fairness in 403 relation to the jaguar differently from farmers as ranchers are directly affected by predation; 
404 whilst farmers could offer more of an outsider perspective, possibly reacting similarly to

405 ranchers, but tending to reflect greater concerns for the community (Parris et al., 2014).

406 Farmers were selected randomly, while ranchers were selected using a snowball technique

407 (Coleman, 1958), where we randomly chose a house in each community to ask members of

408 the household if they could provide us with the names of livestock owners in the community.

409 This approach was used due to the limited number of ranchers in most communities. As the

410 main interest of this study was to understand ranchers' perceptions of justice, we interviewed

411 more ranchers $(n=144)$ than farmers $(n=91)$. Of those people who were at home when we

412 visited the communities, only three individuals refused to participate in the interviews,

413 because of lack of time. None of the people interviewed refused to answer any question from

414 the survey questionnaire.

415 Our questionnaire used closed and open-ended questions and was divided into two

416 sections. The first section comprised demographic and a series of categorical questions to

417 investigate external factors that can influence feeling of justice. We adapted factors identified

418 in Table 1 for the case of jaguar management (Table 2). As categorical questions might not

419 capture the complexity of a particular situation, we asked questions based on information

420 provided by local people in previous studies (see Lecuyer et al., 2018). Indeed, while some

421 questions were simple to adapt, others required an understanding of the region and several

422 iterations of pilot interviews with local actors to articulate clearly (see appendix 1). Because

423 of the limited number of variables we could include in the analysis, in Table 2 we present

424 only the questions from which we extracted the variables included. Some questions originally

425 included more potential answers; answers that were never selected by participants were

426 excluded from the analysis. 
Table 2. Questions to assess external factors regarding jaguar management.

$\begin{array}{ll}\begin{array}{l}\text { Category of } \\ \text { external factor }\end{array} & \text { External factor }\end{array}$

\begin{tabular}{|c|c|c|}
\hline \multirow[t]{3}{*}{$\begin{array}{l}\text { Related to the } \\
\text { injustice itself }\end{array}$} & Responsibility & $\begin{array}{l}\text { - Who do you think is responsible for jaguar management in the region? } \\
\text { 1) Individuals, 2) Government, 3) Reserve, 4) NGOs, 5) Ejido } \\
\text { authorities } \\
\text { - Do you think the responsible (chosen above) 1) Is investing enough } \\
\text { effort to avoid jaguar attack on livestock? 2) Does not care about jaguar } \\
\text { attack on livestock? 3) No opinion } \\
\text { - In your opinion, in which order (from most to least) do these predators } \\
\text { perpetrate attacks? Jaguar, Puma, Dogs, Coyotes, Other (If no risk was } \\
\text { associated with a species, a zero was written) }\end{array}$ \\
\hline & Intentionality & - Do you think jaguar attacks are 1) Controllable? 2) Non-controllable? \\
\hline & Frequency* & - How do you perceive jaguar attack? 1) Uncommon, 2) Frequent \\
\hline \multirow[t]{3}{*}{$\begin{array}{l}\text { Related to the } \\
\text { individual }\end{array}$} & $\begin{array}{l}\text { Individual } \\
\text { characteristics }\end{array}$ & $\begin{array}{l}\text { - Activity: 1) Rancher, 2) Farmer } \\
\text { - Gender } \\
\text { - Age } \\
\text { - Education } \\
\text { - Number of sheep } \\
\text { - For farmers only: Did any jaguar attack on livestock ever occur in your } \\
\text { - } \text { Fommunity? } \\
\text { livestock? }\end{array}$ \\
\hline & Motivation & $\begin{array}{l}\text { - In light of the current situation surrounding the jaguar, would you like } \\
\text { to: 1) Permit an equilibrium between jaguar protection and livestock } \\
\text { production? 2) Increase livestock production? }\end{array}$ \\
\hline & $\begin{array}{l}\text { Environmental } \\
\text { identity }\end{array}$ & $\begin{array}{l}\text { - Choice of propositions to categorize their environmental identity (see } \\
\text { Stet and Biga, 2003) Creation of an index centred on 0, varying from -1 } \\
\text { to } 1 \text {. }\end{array}$ \\
\hline $\begin{array}{l}\text { Related to } \\
\text { contextual } \\
\text { factors }\end{array}$ & $\begin{array}{l}\text { Physical } \\
\text { environment }\end{array}$ & $\begin{array}{l}\text { - How often do you go into the forest? 1) Every day, 2) Once a week, 3) } \\
\text { Once a month, 4) Once a year } \\
\text { - How often do you see wild animals? 1) Every day, 2) Once a week, 3) } \\
\text { Once a month, 4) Once a year }\end{array}$ \\
\hline
\end{tabular}



Intra-group - How do you best identify yourself? 1) By your activity (rancher or relationships farmer), 2) By your status in your community (ejidatario or non ejidatario), 3) By the community in which you live (name of the community)?
- Within the group you best identify yourself, regarding jaguar management, do you: 1) Share the same opinion? 2) Have a different opinion?
Inter-group relationships
- Which of the following actors do you think have the right to be involved in jaguar management? (several answers possible) 1) Government, 2) Reserve, 3) NGOs, 4) Ejidos authorities, 5) Individuals
- Do you think the jaguar management actions implemented by this/these actor(s) have been adequate? 1) Yes, 2) No general.

* We replaced the external factor "duration" (of attacks taking place) by "frequency" (of attacks) to avoid biases caused by respondents being engaged in this activity for very different durations.

The second section of the questionnaire was an assessment of participants' feelings of justice. During previous research in the region, we identified 16 criteria that people used to build their perceptions of justice according to the four dimensions of justice considered here (Lecuyer et al., 2018). Those criteria were described in 18 statements (Table 3, Appendix 1). We first asked participants if they agreed or disagreed with these statements to confirm our framing of the criteria of justice. Following, we asked them to select the 10 most important statements for them, without ranking. Out of those 10 statements, participants had to choose the most important statement out of each pair of statements (45 paired comparisons in total). We chose paired comparisons because according to previous studies (Cattelan, 2012) and our experience in the region, people struggle to rate or rank several items and our pilot interviews showed that it was easier to compare pairs of items. The interview ended with open questions 
Table 3. Statements that were the objects of paired comparisons and represent different justice

450 criteria that are associated with different justice dimensions. The letters associated with the

451 criteria are not in alphabetical order because we wished to present the criteria randomly to our participants without the possibility for preconceived ranking.

\begin{tabular}{|c|c|c|}
\hline Theme & Criterion & Statement \\
\hline \multirow{5}{*}{$\begin{array}{l}\text { Distributive } \\
\text { environmental justice: } \\
\text { the fair distribution of } \\
\text { costs and benefits } \\
\text { related to jaguar } \\
\text { management }\end{array}$} & i. Need-Benefit & $\begin{array}{l}\text { Support should be provided to the livestock breeders } \\
\text { who need it most }\end{array}$ \\
\hline & k. Equality-Benefit & The same support should be provided to everyone \\
\hline & m. Merit-Cost & $\begin{array}{l}\text { Conservationists should pay for the cost of living with } \\
\text { jaguars }\end{array}$ \\
\hline & o. Merit-Benefit & $\begin{array}{l}\text { Support should be provided to those who take } \\
\text { measures to coexist with, and protect, jaguars }\end{array}$ \\
\hline & r. Equality-Benefit & $\begin{array}{l}\text { The cost of living with the jaguar should be distributed } \\
\text { among all }\end{array}$ \\
\hline \multirow{6}{*}{$\begin{array}{l}\text { Procedural } \\
\text { environmental justice: } \\
\text { the fairness of the } \\
\text { processes of jaguar } \\
\text { management (daily } \\
\text { based operation) }\end{array}$} & c. Compliance & Everybody should respect the decisions taken \\
\hline & d. Consistency & $\begin{array}{l}\text { There should be no interest group favoured during the } \\
\text { decision-making process }\end{array}$ \\
\hline & j. Opportunity for revision & $\begin{array}{l}\text { If I disagree with a decision, I should be able to give } \\
\text { my opinion }\end{array}$ \\
\hline & 1. Trust & $\begin{array}{l}\text { People in charge of making decisions should be people } \\
\text { I trust }\end{array}$ \\
\hline & p. Representation & $\begin{array}{l}\text { Everyone should have the opportunity to give their } \\
\text { opinion during the decision-making process }\end{array}$ \\
\hline & q. Respect & $\begin{array}{l}\text { Those responsible for jaguar management should treat } \\
\text { me with respect }\end{array}$ \\
\hline \multirow{3}{*}{$\begin{array}{l}\text { Ecological justice: the } \\
\text { fair and respectful } \\
\text { treatment of jaguar }\end{array}$} & $\begin{array}{l}\text { a. Right of the } \\
\text { environment }\end{array}$ & Jaguars have the right to live \\
\hline & $\begin{array}{l}\text { f. Responsibilities towards } \\
\text { other species }\end{array}$ & $\begin{array}{l}\text { I am responsible for not putting at risk a jaguar and its } \\
\text { habitat }\end{array}$ \\
\hline & $\begin{array}{l}\text { n. Responsibilities to } \\
\text { future generation }\end{array}$ & $\begin{array}{l}\text { I want to protect the jaguar for my children and } \\
\text { grandchildren to be able to know it }\end{array}$ \\
\hline \multirow{4}{*}{$\begin{array}{l}\text { Justice as recognition: } \\
\text { acknowledging land- } \\
\text { use rights, values and } \\
\text { knowledge systems }\end{array}$} & b. Plurality of interest & $\begin{array}{l}\text { Those responsible for jaguar management should } \\
\text { recognize the importance of everyone's interest }\end{array}$ \\
\hline & e. Land-use right & $\begin{array}{l}\text { I should have the right to do what I want, if a jaguar is } \\
\text { on my land }\end{array}$ \\
\hline & g. Neutral approach & $\begin{array}{l}\text { Those responsible for jaguar management should be } \\
\text { neutral }\end{array}$ \\
\hline & h. Knowledge & $\begin{array}{l}\text { Jaguar management should be based on what we know } \\
\text { about the jaguar }\end{array}$ \\
\hline
\end{tabular}




\subsection{Data analysis}

455 Our analysis presupposed that study participants make choices between different criteria of 456 justice to build their overall perception, and that those choices will be influenced by external 457 factors (covariate) related to the injustice, the individual and the context. Those choices are 458 not identical with ranking or grading a proposition as we had multiple cases of nontransitivity in our dataset (i.e. a participant might rank $a>b>c$ but $c>a$ ). In fact, our dataset showed an appreciable number of non-transitivity cases: 3218 cases of non-transitivity out of 28200 (11.41\%). Thus, we decided not to include the implicit comparisons between the 10 criteria selected and the 8 unselected criteria in our analyses. The analysis of the effect of the external factors focused only on the explicit comparisons made among the 10 criteria selected by each participant. These choices can be analysed with the Bradley-Terry-Luce model using paired comparisons (Bradley and Terry, 1952). However, the Bradley-Terry-Luce model assumes that the strengths of the objects compared are equal for all subjects selecting them

467 (Cattelan, 2012). Schauberger and Tutz (2017) proposed a methodology that accounts for 468 heterogeneity of both the subject (person) making the comparison, and the object (criteria) 469 being compared. They incorporated a LASSO penalty to select subject-specific or criteria470 specific covariates into the Bradley-Terry-Luce model. By using a penalized likelihood 471 approach, the Bradley-Terry-Luce model with LASSO penalty (BTLLasso) allowed us to 1) 472 compare pairs of criteria from choices made by different participants; 2) identify clusters of 473 criteria influenced similarly by a covariate; and, 3) assess the subject-covariate that influenced 474 choices among pairs of criteria (Schauberger and Tutz, 2017). In short, the BTLLasso 475 proposes the modulation of justice criteria by subject-specific covariates selected using a 476 LASSO penalty weighted by a tuning parameter. Because the importance of the LASSO 477 penalty may vary depending on the data in question, we used a cross-validation to choose the 
tuning parameter and thus a penalty level adequate for the data for which the model was constructed. By choosing an appropriate penalty level, we can visualize justice criteria that share the same strength as well as those that can be distinguished from other justice criteria (Schauberger and Tutz, 2017). To evaluate the quality of the models obtained, we randomly sampled the data with replacement (bootstrap) 200 times and used these bootstrap iterations to build 95\% confidence intervals. By using BTLLasso, we represented 1) how external factors influenced the perception of the subjects among justice criteria and 2) the influence that specific external factors have on the different justice criteria. All Bradley-Terry-Luce models were constructed using the BTLLasso R package. More details about the Bradley-Terry-Luce models we built can be found in Supplementary material 2.

In addition, we explored how similarly justice criteria were affected by external factors. We built a matrix of estimated effects (i.e. the effect values for the optimal model) for each criterion of every group of external factors and for every external factor. We then used Kmeans partitioning (Legendre and Legendre 2012, section 8.8) to group criteria based on how similarly they are influenced by external factors. K-means partitioning assigns each criterion to a specific cluster and optimizes the assignment through an iteration process. In K-means partitioning, the number of clusters is defined a priori. Here, we intended to group criteria in two to ten clusters. To find the optimal number of clusters we used the Calinski-Harabasz criterion (Calinski and Harabasz, 1974). To perform this analysis, we used the cascadeKM function available in the vegan R package (Oksanen et al. 2017).

3. Results
3.1. General results on external factors 
501 Our interviews provided information on the participants and allowed us to explore people's

502 perception of the injustice itself and of their interaction with their social and natural

503 environment (Table 4).

504 


$\begin{array}{ll}\begin{array}{l}\text { Category of } \\ \text { external factor }\end{array} & \text { External factor }\end{array}$

\begin{tabular}{|c|c|c|}
\hline \multirow[t]{3}{*}{$\begin{array}{l}\text { Related to the } \\
\text { injustice itself }\end{array}$} & Responsibility & $\begin{array}{l}\text { Ejido authorities }=12(\text { Positively }=8, \text { Negatively }=3, \text { No opinion }=1) \\
\text { Everyone }=22(\text { Positively }=5, \text { Negatively }=13, \text { No Opinion }=4) \\
\text { Government }=75(\text { Positively }=24, \text { Negatively }=45, \text { No Opinion }=6) \\
\text { NGO }=20(\text { Positively }=7, \text { Negatively }=12, \text { No Opinion }=1) \\
\text { Reserve }=106(\text { Positively }=32, \text { Negatively }=64, \text { No Opinion }=10) \\
\text { - Species deemed responsible: Range }=0-1 ; \text { Average score: Jaguar }= \\
\text { 0.9; Puma }=0.4\end{array}$ \\
\hline & Intentionality & - Jaguar attacks are: Controllable $=73 ;$ Non-controllable $=162$ \\
\hline & Frequency & 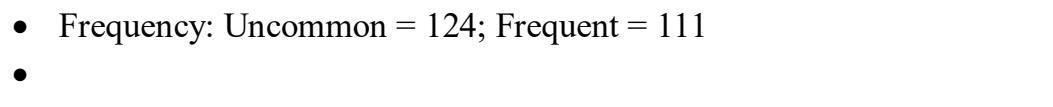 \\
\hline \multirow[t]{3}{*}{$\begin{array}{l}\text { Related to the } \\
\text { individual }\end{array}$} & $\begin{array}{l}\text { Individual } \\
\text { characteristics }\end{array}$ & $\begin{array}{l}\text { - Activity: Rancher }=144 ; \text { Farmer }=91 \\
\text { - Gender: } \mathrm{M}=160 ; \mathrm{W}=75 \\
\text { - Age: } \text { Range }=19-83 ; \text { Mean }=47 ; \mathrm{SD}=15 \\
\text { - } \text { Education (number of years): Range }=0-15 ; \text { Mean }=6 ; \mathrm{SD}=4 \\
\text { - Number of sheep: Range }=2-300 ; \text { Mean }=32 ; \mathrm{SD}=27 \\
\text { - } \text { Farmers only: Attack in community }=54 ; \text { No attack in community }=37 \\
\text { - Ranchers only: Attack }=100 ; \text { No attack }=44\end{array}$ \\
\hline & Motivation & $\begin{array}{l}\text { - Equilibrium between jaguar protection and livestock production }=126 \\
\text { Increase livestock production }=109\end{array}$ \\
\hline & $\begin{array}{l}\text { Environmental } \\
\text { identity }\end{array}$ & $\begin{array}{l}\text { - Environmental identity index: Range }=-0,66-1 ; \text { Mean }=0.28 ; \mathrm{SD}= \\
0.45\end{array}$ \\
\hline \multirow[t]{3}{*}{$\begin{array}{l}\text { Related to } \\
\text { contextual } \\
\text { factors }\end{array}$} & $\begin{array}{l}\text { Physical } \\
\text { environment }\end{array}$ & $\begin{array}{l}\text { Number of days per year during which they go into the forest and/or } \\
\text { observe wild animals: } \\
\text { Range=2-730; Mean }=258 ; \mathrm{SD}=237\end{array}$ \\
\hline & $\begin{array}{l}\text { Intra-group } \\
\text { relationships }\end{array}$ & $\begin{array}{l}\text { Activity }=44(\text { Same opinion }=17 ; \text { Various opinions }=27) \\
\text { Status }=84(\text { Same opinion }=31 ; \text { Various opinions }=53) \\
\text { Community }=107(\text { Same opinion }=33, \text { Various opinions }=74)\end{array}$ \\
\hline & $\begin{array}{l}\text { Inter-group } \\
\text { relationships }\end{array}$ & $\begin{array}{l}\text { - Government: Not adequate }=95, \text { Not involved }=30, \text { Adequate }=110 \\
\text { Reserve: Not adequate }=63, \text { Not involved }=26, \text { Adequate }=146 \\
\text { NGO: Not adequate }=65, \text { Not involved }=38, \text { Adequate }=132 \\
\text { Ejido } \text { authorities: Not adequate }=57, \text { Not involved }=29, \text { Adequate }=149 \\
\text { Everyone: Not adequate }=37, \text { Not involved }=30, \text { Adequate }=168\end{array}$ \\
\hline
\end{tabular}


511 The first part of the interview indicated if participants $(n=235)$ agreed with the statement

512 related to each criterion (dark shaded column, Fig. 1) and which ones they selected as their

513 ten most important (light grey column, Fig. 1). Some criteria $(a, n, o, p, q)$ stood out since

514 almost $95 \%$ of the participants agreed with these statements and because they were often

515 chosen in the ten most important criteria ( $>74 \%)$. Conversely, a few criteria showed lower

516 levels of agreement (45-60\%) among participants $(e, g)$ or had lower importance (10-40\%) $(d$,

$517 e, g, r)$.

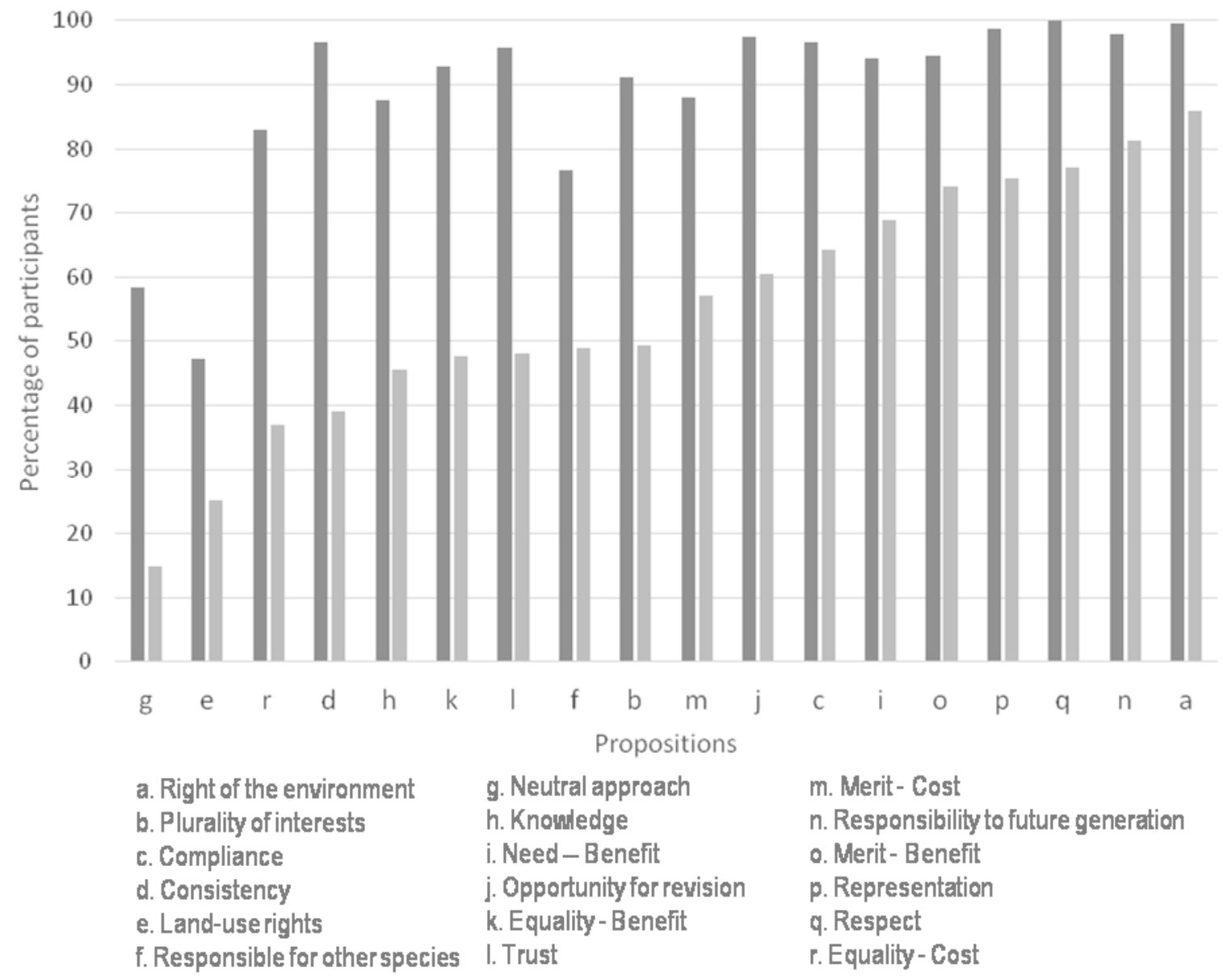

Figure 1. Agreement with the criteria presented (dark grey) and criteria selected among the ten most important (light grey) by participants $(n=235)$. Criteria are presented in increasing order of selection by participants among the ten most important criteria. 
525 The BTLLasso analyses resulted in 43 plots (see Appendix 2). Due to the high number of 526 resulting figures, we created three sub-figures to visually synthesize our results and show 527 some of the main trends (Fig. 6). However, each individual result is also of interest and while 528 we cannot illustrate all of these in the results, we use some findings to illustrate points made 529 in the discussion.

Injustice itself - Looking at factors related to the injustice itself allowed us to explore

531 the effects of the nature of the injustice in question on participants' perception of justice.

532 First, we found that the effect of who participants perceived to be responsible is not

533 straightforward; if participants felt that those they believed were responsible for jaguar

534 management were undertaking their roles effectively, this had a stronger effect than merely

535 attributing responsibility (Fig. 2). Second, feeling that everyone (including themselves) or the 536 ejido authorities was responsible (either if they were fulfilling their roles effectively or not)

537 influenced strongly participants' feelings of justice. There was less influence if responsibility

538 was allocated to an entity such as the reserve or NGOs ${ }^{2}$. Third, the perceived control and

539 frequency of attacks were important in determining the feelings of justice of participants.

\footnotetext{
${ }^{2}$ External factors highlighted as influential were not necessarily selected by a majority of participants. For example, only 22 participants perceived individuals to be responsible for jaguar management, against 135 who perceived the Reserve to be responsible. Moreover, the way the 22 participants perceived individuals to be responsible led them to perceive and prioritize the criteria of justice differently in comparison to the other participants.
} 


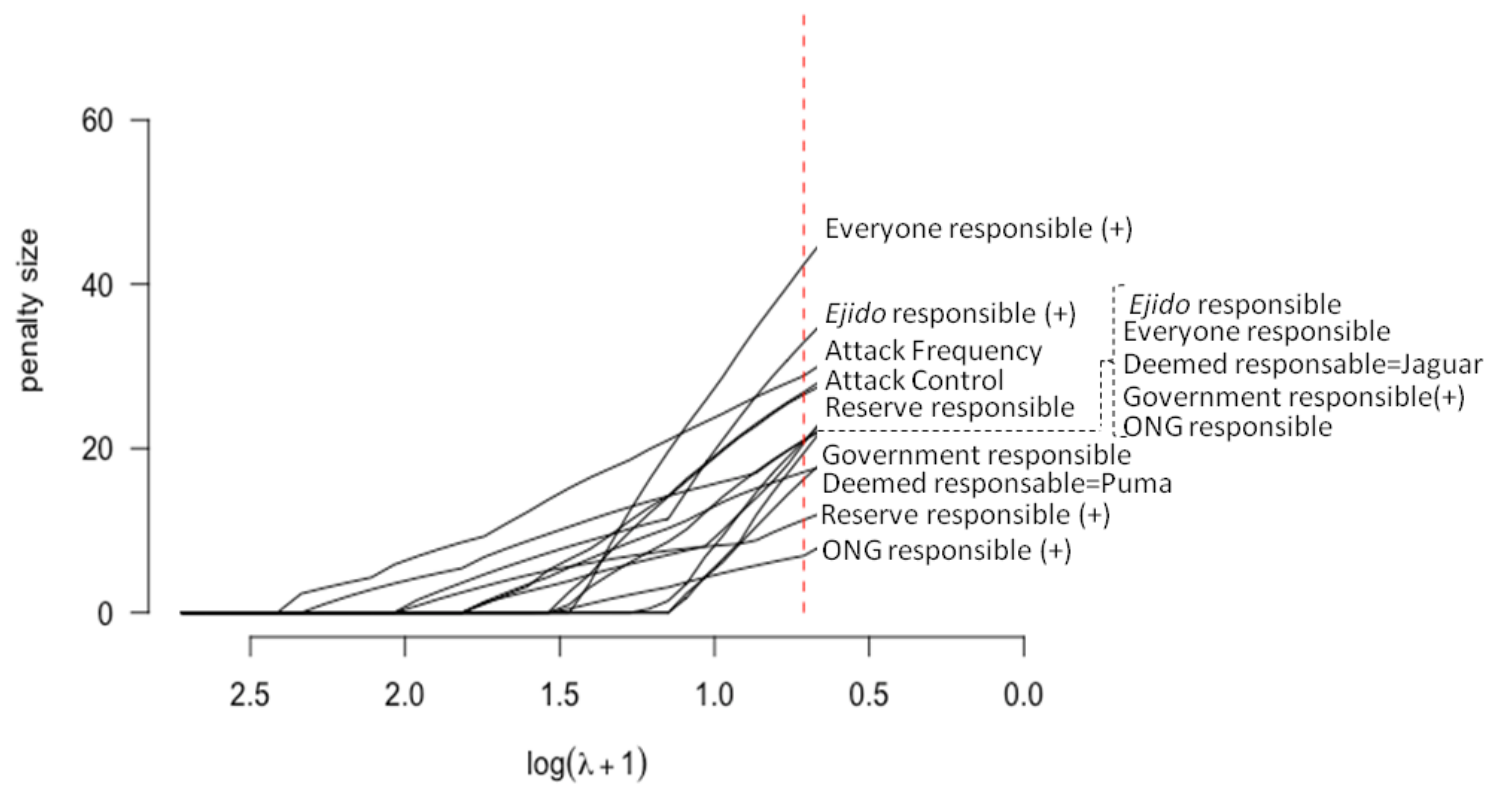

541 Figure 2. Penalty paths for injustice factors. $\lambda$ (a tuning parameter) specifies the seriousness of 542 the penalty term. The dashed red line represents the optimal model following a 5-fold cross543 validation. Subject-specific covariate "Everyone responsible $(+)$ " had the largest penalty for 544 the single model component at the optimal value of the tuning parameter; hence, it was the 545 covariate that most influenced participants' choices among the criteria evaluated.

Individual - At the individual level (Fig. 3), environmental identity was the factor that most influenced participants' perception of fairness. Environmental identity was followed by 549 gender, personal motivation regarding jaguar management (i.e. more livestock or an 550 equilibrium between jaguar protection and livestock production), farmers' knowledge of 551 jaguar attack occurrence in their community, and education. However, factors related to a 552 rancher's experience were relatively unimportant (e.g. previous experience of attacks, number 553 of sheep owned). External factors such as activity and age were not very important either. 


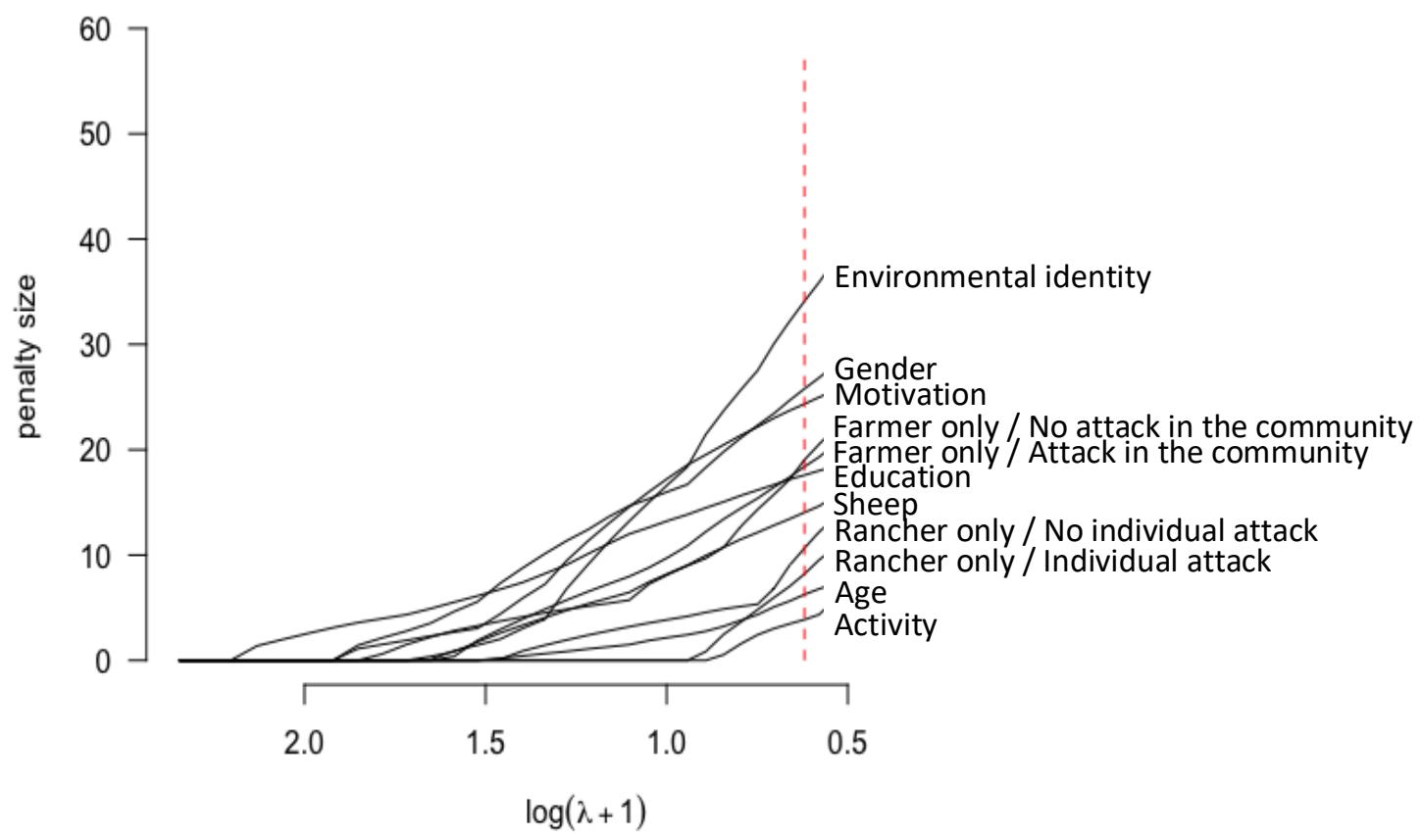

555

556 Figure 3. Penalty paths for individual factors. $\lambda$ (a tuning parameter) specifies the seriousness 557 of the penalty term. The dashed red line represents the optimal model following a 5-fold 558 cross-validation. Subject-specific covariate "environmental identity" had the largest penalty 559 for the single model component at the optimal value of the tuning parameter; hence, it was the 560 covariate that most influenced participants' choices among the criteria evaluated.

563 group relationships) was the most important factor explaining feelings of justice (Fig. 4). This

564 was especially the case when people defined their main group affiliation by their main activity

565 (i.e. farmer or rancher) and believed they had a different opinion toward jaguar management

566 from the rest of this group; or when they affiliated to the community with feelings that they

567 had either similar or divergent opinion with the rest of the community. Inter-group

568 relationships (i.e. how they perceived management entities) had less influence on feelings of

569 justice, but allowed us to evaluate how views on the efficacy of organisations influenced their

570 feelings. Interaction with the physical environment had very little effect on people's 


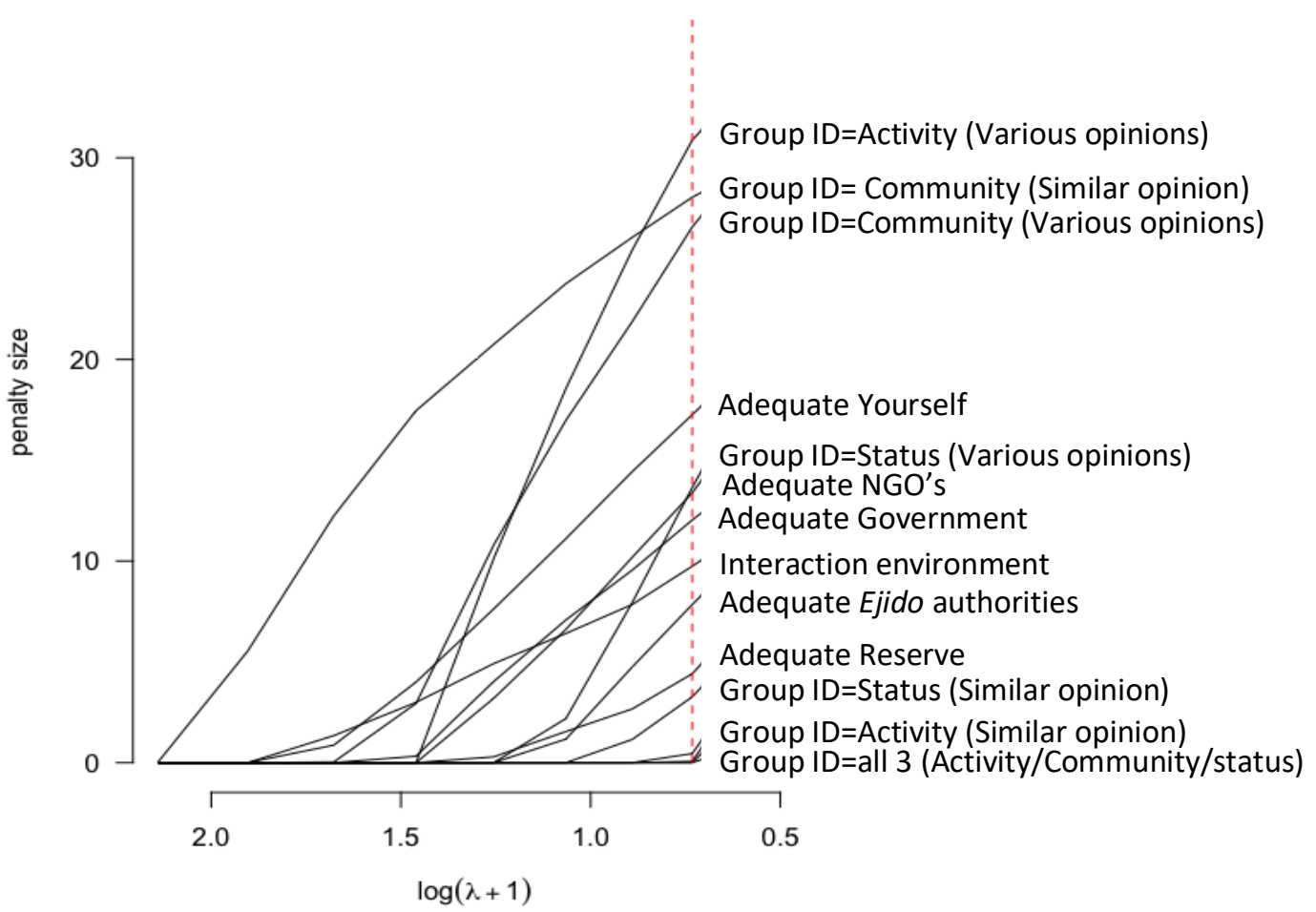

575 Figure 4. Penalty paths for contextual factors. $\lambda$ (a tuning parameter) specifies the seriousness

576 of the penalty term. The dashed red line represents the optimal model following a 5-fold cross-validation. Subject-specific covariate "Group ID=Activity (Various opinions)" had the largest penalty for the single model component at the optimal value of the tuning parameter; hence, it was the covariate that most influenced participants' choices among the criteria evaluated.

3.3. External factors influence on criteria

583 The BTLLasso analysis also made it possible to study the effects of external factors on the 584 selected criteria. The effects of individual external factors $(n=43)$ are shown in detail in Appendix 2; we present here one original graph that was a direct output from the BTLLasso analysis and additional selected results in figure 6 built from data obtained through BTLLasso 
results. As it would be impossible to present all the results in detail here, for the purpose of

588 this paper we show how the results can be analysed in different ways. We display examples

589 of the effects of one specific factor on every criterion, a comparison of the effects of various

590 external factors on the criteria, and how one specific criterion is influenced by all external

591 factors.

592 Specific factors - We wanted to understand how the effect of suffering jaguar attacks

593 might affect different criteria of justice (Fig. 5), even though jaguar attack had less influence

594 on feelings of justice than many other external factors (see Fig. 4). This analysis demonstrated

595 that ranchers who suffered an attack perceived the right to live of the jaguar (a) to be more

596 important than ranchers who had never experienced an attack. The former placed less

597 importance on having an equal share of the benefit of living with jaguars $(k)$, not favouring

598 any interest group during the decision-making process $(d)$ or having those responsible for

599 jaguar management recognizing the importance of everyone's interest $(b)$. They also

600 considered trust $(l)$ in the decision maker to be less important.

601

602

603

604 


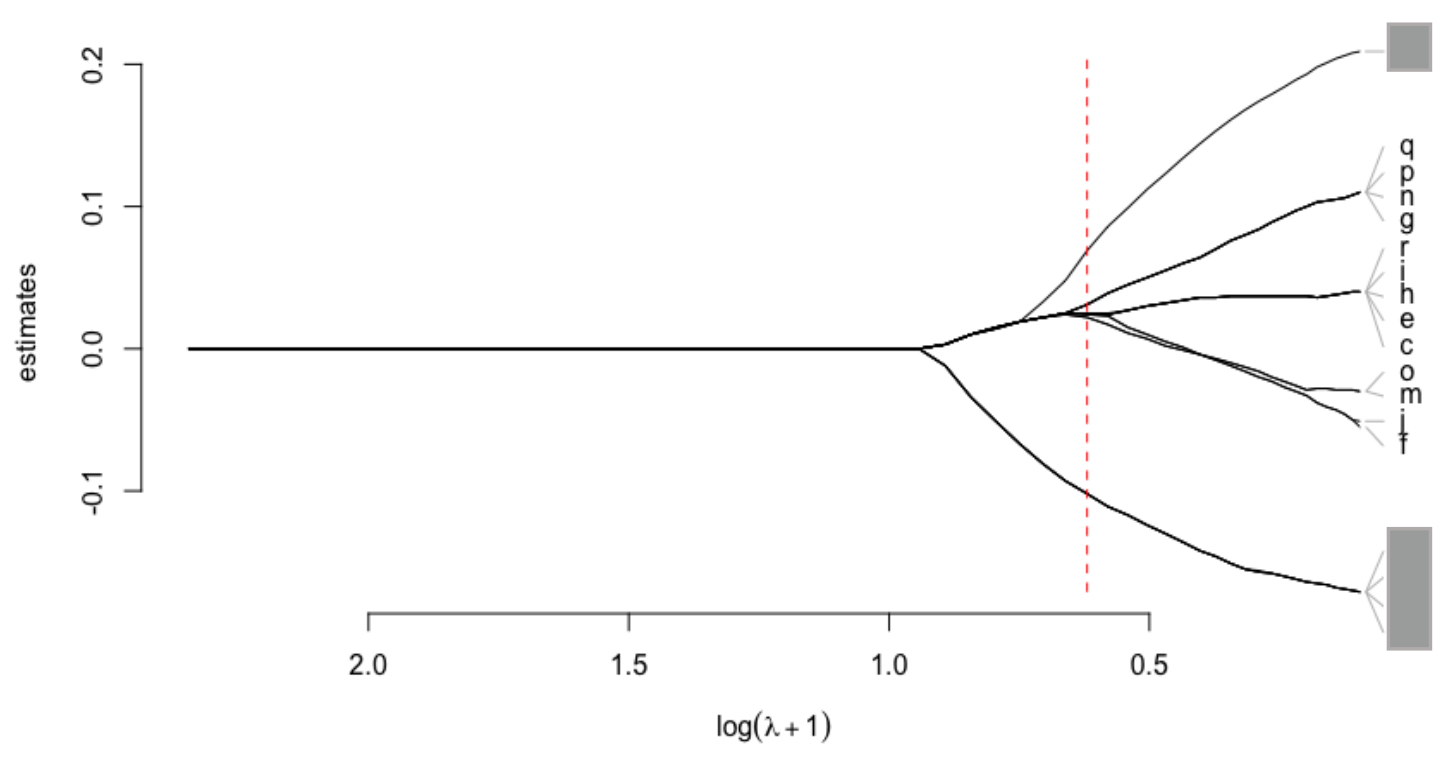

605

606 Figure 5. Parameter paths for the subject-specific variable, when participants were ranchers

607 who had suffered a livestock attack. $\lambda$ (a tuning parameter) specifies the seriousness of the

608 penalty term. The dashed red line represents the optimal model following a 5-fold cross-

609 validation. The plot is centered on 0 on the $\mathrm{Y}$-axis. Parameter paths with a positive (negative)

610 value indicate a positive (negative) relationship of the criteria for the variable of interest. For

611 the optimal model (dashed red line), criteria following the same paths (e.g. $g$ and $o$ ) should be

612 given equal importance in the interpretation. See figure 1 for the list of criteria.

613

Comparison of the effects of various external factors - When comparing external

615 factors, it was possible to compare, for example, how different perceptions of jaguar

616 management held within the same group influenced jaguar management (Fig. 6c). The

617 participants who expressed a strong sense of belonging in their community and who perceived

618 that they shared the same opinion regarding jaguar management as their community were less

619 inclined toward an equal distribution of costs and benefits $(k, r)$, and more toward helping

620 people with greater needs (i); they felt that conservationists should bear the costs of living

621 with jaguars $(\mathrm{m})$. These participants also considered individual responsibility (f) to be less

622 important in jaguar management. On the other hand, participants who expressed a strong

623 sense of belonging in their community, but who said that opinions regarding jaguar

624 management diverged within their community, had different priorities regarding justice. 
625 Criteria they felt were important included equal distribution of costs and benefits $(k, r)$,

626 recognition of efforts to coexist with jaguars (merit, o), individual responsibility $(f)$ and 627 recognition of their knowledge (h).

628 


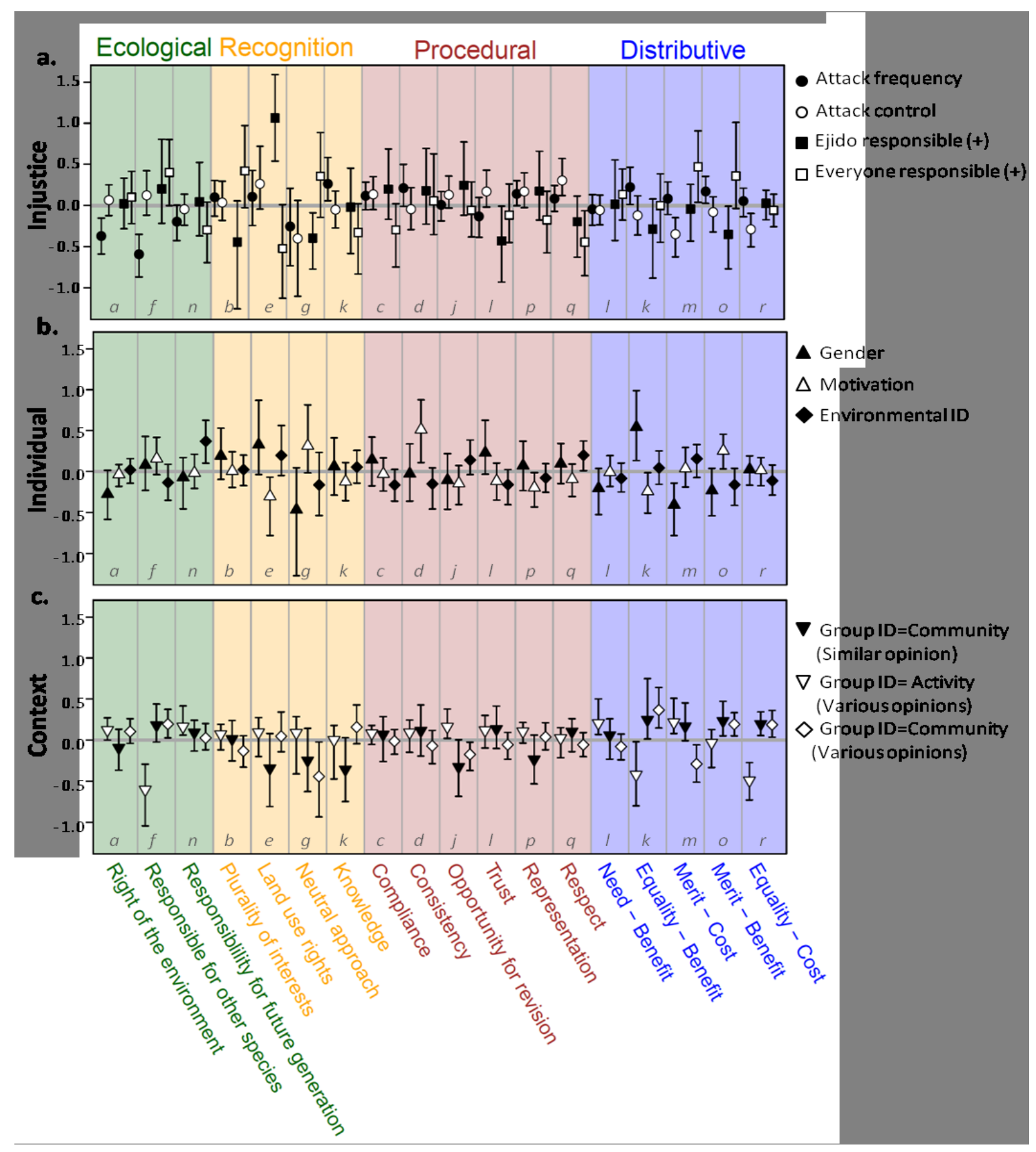

Figure 6. Summary of the effects of the most influential external factors (i.e. highest penalty

631 size) on the perceived importance of justice criteria for (a) external factors related to the

632 injustice, (b) external factors related to the individual, and (c) external factors related to the

633 context. Criteria are grouped by dimension of justice: ecological, justice-as-recognition,

634 procedural and distributive. The $\mathrm{Y}$-axis of each figure represents the estimates of the effect

635 and is centered on zero. Positive (negative) value indicate a positive (negative) relationship of

636 the criteria for the variable of interest. Confidence intervals for subject-specific variables (e.g.

637 gender) are based on 200 bootstrapped samples. 
639 influenced a specific criterion. For example, which criteria relating to ecological justice affect

640 perceptions of jaguar management? In Calakmul, feeling that everyone should be responsible

641 for jaguar management was related to an increased sense of personal responsibility toward

642 jaguar management (f) (Fig. 6a). Participants who identified strongly as community members

643 were less willing to consider individual responsibility $(f)$ when they thought that other

644 community members had similar attitudes toward jaguar management (Fig. 6c). Respondents

645 who showed a strong environmental identity indicated that their responsibility for future

646 generations (n) was important (Fig. 6b). Finally, perceptions of attacks as being frequent led

647 respondents to acknowledge that all three criteria linked to ecological justice (Fig. 6a) were

648 less important.

649 To develop just and effective jaguar management plans, it is also necessary to explore

650 what motivates people to consider that they have the right to do whatever they want with

651 jaguars on their land (e). Our results indicated that respondents who both deemed attacks to be

652 frequent and believed they cannot control attacks were more inclined to give importance to

653 the right to do what they want when a jaguar is on their land (e) (Fig. 6a). Similar views were

654 held by those who perceived positively the ejido authorities as responsible for jaguar

655 management; on the opposite, it is not the case for those who perceive positively that

656 everyone is responsible for jaguar management (Fig. 6a). Men were also more inclined to put

657 more importance on land-use rights. Interestingly, those who expressed their wish to have

658 more livestock gave less importance to land-use rights, while those with a strong

659 environmental identity gave it more importance (Fig. 6b). Finally, participants who based

660 their main group affiliation on their main economic activity (farmer or rancher) and who

661 believed they had divergent opinions on jaguar management perceived their land-use right to

662 be less important (Fig. 6c). 
664 The K-mean partitioning did not allow identifying a clear number of groups using the

665 Calinski-Harabasz criterion (see Appendix 3). However, the Calinski-Harabasz criterion

666 yielded the largest increase when the criteria were partitioned in four groups. Using these four 667 groups we compared our initial division of the criteria among the four dimensions of justice.

668 We explored the effect of each group of external factors and of every external factor on each 669 criterion, allowing us to identify trends (Table 5). The external factors related to injustice 670 suggest that there may be specific influences, for example, on how people perceive their land671 use right (e) and the importance of both a plurality of interests (b) and a neutral approach (g), 672 and the importance of both the right to live of the jaguar (a) and their own responsibility for 673 its survival (f). Furthermore, we were able to compare our initial grouping of the criteria 674 (according to procedural, distributive, ecological and recognition forms of justice) with the 675 final grouping of the criteria according to the influence of external factors (injustice, 676 individual, context): 1) Each criterion of distributive justice (merit, $m, o$, need, $i$, equality, $k$, $677 r$ ) was represented in a different group; 2) Every criterion of procedural justice $(c, g, l, p, q)$ 678 was influenced similarly by the external factors of justice except for the consistency criterion 679 (d), which was more associated with criteria related to justice-as-recognition: neutrality ( $g$ ) and plurality of interests (b); 3) Knowledge criteria (h) that were associated with justice-as-

681 recognition seemed to be affiliated with procedural justice concerns and to be perceived more 682 at the decision-making process level; 4) Land-use rights (e) criteria responded differently 683 from all other criteria to the influence of external factors; 5) Ecological justice was divided in 684 two: while the rights of the species (a) and responsibilities to future generations (n) seemed to 685 go hand in hand with people's concerns regarding procedural justice and the need (i) for 686 criteria of distributive justice, individual responsibility $(f)$ for jaguar management seemed to 687 be influenced differently and related to the equality criteria $(k, r)$ of distributive justice. 
688 Table 5. Grouping patterns of criteria according to the external factors evaluated (injustice, 689 individual, and context). The table shows the groups formed at level 4 of the K-mean 690 partitioning. Our original grouping of criteria included four dimensions of justice: ecological 691 (a, f, n; in green); recognition (b, e, g, h; in orange); procedural (c, d, j, l, p, q; in brown); 692 distributive (i, $\mathrm{k}, \mathrm{m}, \mathrm{o}, \mathrm{r}$; in blue).

693

\begin{tabular}{|c|c|c|c|c|}
\hline External factor & Group 1 & Group 2 & Group 3 & Group 4 \\
\hline Injustice & $\begin{array}{l}\mathrm{n} \\
\mathrm{h}, \\
\mathrm{c}, \mathrm{d}, \mathrm{j}, \mathrm{l}, \mathrm{p}, \mathrm{q}, \\
\mathrm{i}, \mathrm{k}, \mathrm{m}, \mathrm{o}, \mathrm{r},\end{array}$ & $\mathrm{a}, \mathrm{f}$ & $\mathrm{b}, \mathrm{g}$, & $\mathrm{e}$ \\
\hline Individual & $\begin{array}{l}\text { a, n, } \\
\mathrm{e}, \mathrm{h}, \\
\mathrm{j}, \mathrm{q}, \\
\mathrm{i}, \mathrm{m}\end{array}$ & $\begin{array}{l}\text { f, } \\
\mathrm{b}, \\
\mathrm{c}, 1, \mathrm{p}, \\
\mathrm{k}\end{array}$ & $\begin{array}{l}\mathrm{g}, \\
\mathrm{d}, \\
\mathrm{o}\end{array}$ & $\mathrm{r}$ \\
\hline Context & $\begin{array}{l}\mathrm{a}, \\
\mathrm{e}, \mathrm{h}, \\
\mathrm{j}, \mathrm{p},\end{array}$ & $\begin{array}{l}\mathrm{n} \\
\mathrm{b}, \\
\mathrm{c}, \mathrm{d}, \mathrm{l}, \mathrm{q}, \\
\mathrm{i} \mathrm{m}, \mathrm{o},\end{array}$ & g & $\begin{array}{l}\mathrm{f}, \\
\mathrm{k}, \mathrm{r}\end{array}$ \\
\hline $\begin{array}{l}\text { All external } \\
\text { factors together }\end{array}$ & $\begin{array}{l}\mathrm{a}, \mathrm{n}, \\
\mathrm{h}, \\
\mathrm{c}, \mathrm{j}, \mathrm{l}, \mathrm{p}, \mathrm{q}, \\
\mathrm{i}\end{array}$ & $\begin{array}{l}\mathrm{g}, \mathrm{b}, \\
\mathrm{d}, \\
\mathrm{m}, \mathrm{o}\end{array}$ & $\mathrm{e}$ & $\begin{array}{l}\mathrm{f}, \\
\mathrm{k}, \mathrm{r}\end{array}$ \\
\hline
\end{tabular}

694

\section{Discussion}

696 This study aimed to explore participants' perception of justice regarding jaguar management 697 in the Calakmul region of Mexico. Our analysis did not identify a dominant perception of 698 justice (e.g. Sikor et al., 2014), but instead highlighted variability among people's perception 699 of justice. Overall feeling of fairness meant different things for different people. For instance, 700 for some participants, unfairness lay in the killing of jaguars, while for others, unfairness lay 701 in the losses of livestock experienced by ranchers. Therefore, we focused on revealing the 702 varied nature of justice perception by making explicit the various criteria at play in local 703 actors' perceptions of justice surrounding jaguar management, and linking them to social dynamics. Our main finding was that an experience of jaguar attack had a weak influence on actors' perception of fairness; rather, perception of fairness was driven mainly by questions of

706 identity and assessments of inter and intra-group relationships. Certain criteria (e.g. own sense 
of responsibility toward jaguar survival) were critical in enabling us to propose solutions toward fairer jaguar management. External factors also strongly influenced some criteria affecting perceptions of fairness (e.g. land-use right, for some participants). Using a powerful statistical approach, we were able to highlight patterns and relationships amongst criteria affecting perceptions of justice, enabling us to contribute to a more holistic perspective of

712 feelings of fairness in conservation.

\subsection{Group identity and self-interest influences on feelings of justice}

We assessed the importance of three groups of factors towards feelings of justice: the first related to the injustice in question, the second to individuals expressing their feelings about the injustice, and the third to the context of the situation. These groups of factors enabled us to explore the roles of self-interest and group identity. An assumption of self-interest indicates that people act mainly in order to maximise a reward (Skitka et al., 2010). However, we found that people did not think this way; being a rancher who had suffered an attack only weakly

721 affected perception of justice. Others have also found that the role of previous experience has 722 a limited influence on fairness perception (Clayton et al., 2016) and that feelings of justice are 723 not related only to the object of the injustice (Kellerhals et al., 1988). More surprisingly, experience of attack at the individual and community levels, respectively for ranchers and farmers, actually increased the perceived importance of jaguars' right to live. Although looking at perception of frequency and control over attacks gave more complex answers, this 727 does not support the assumption of self-interest in perceptions of fairness. However, whilst most perceptions of justice did not reflect self-interest, they did not necessarily reflect a concern for society either. Instead, people seemed to base their feeling of fairness on a

730 common peasant-farmer (campesino) way of living across activities, expressed through their 731 desire of being able to live a decent life in Calakmul. This finding reinforced our previous 
research that local actors aspire to justice for those sharing the campesino identity (Lecuyer et al., 2018).

Our results also supported the group identity assumption that relationships within and

\section{5} between groups are potent determinants of fairness judgments (Lind and Tyler, 1988; Skitka et al., 2010). Actors not only took into consideration their own judgments, but also the conduct and opinions of group members while evaluating fairness (as shown by Clayton et al., 2016; Hegtvedt et al., 2003; Lauber, 1999; Ohl et al., 2008). More importantly, our results indicated that rather than the group with which they identified, it was the perception of the coherence in the opinions toward jaguar management within the group that mattered. This is important, as a lack of coherence within a given group also hinders the willingness of its members to participate in decision-making, because of the lack of a united front to present and defend ideas (Lind and Tyler, 1988). Of importance was also who was perceived as responsible for jaguar management and whether this management was perceived positively. Here, we show how external factors might influence people's sense of responsibility toward jaguar management, which could be of interest for jaguar conservation. Our comparison of intra- and inter-group relationships regarding jaguar management allowed us to uncover some of the influences of groups' values and dynamics on their perception of fairness.

\section{Effects of self-interest and group identity are complex. External factors did not have a} straightforward effect: while some individual factors led people to choose criteria that represent justice for all, including jaguars, external factors related to relationships with others sometimes influenced their choice of criteria in relation to self-interest (e.g. land-use rights). Participants modified their perception of justice not only according to the costs and benefits to be distributed and to whom, but also according to who is in charge of the distribution and how others act regarding jaguar management. Both self-interest and group identity are thus important assumptions to take into consideration for carnivore conservation. In effect, past 
actions emphasized technical measures to reduce losses caused by depredation, assuming concern for self-protection was driving the surrounding conflict (Treves and Karanth, 2003). However, more recently researchers proposed that relational aspects are among the principal

760 drivers of biodiversity conflicts (Redpath et al., 2013). Looking at the influence of external 761 factors on criteria that Calakmul ranchers and farmers used to build their feeling of justice 762 supported others' findings that people can care for both self-interest and group identity 763 (Clayton and Opotow, 2003; Lind and Tyler, 1988).

764

\subsection{Recommendations for jaguar conservation}

We believe acknowledging and exploring the variability in the criteria used by people to assess fairness in jaguar management can provide guidance for the implementation of management plans that encompass various perceptions of justice. One of our main findings was that the vast majority of local actors, ranchers included, recognized the intrinsic right of the jaguar to live and the importance of its survival for future generations. Even more

771 importantly, we uncovered alternative narratives to those currently circulated by

772 conservationists in Calakmul. For instance, even ranchers who had suffered attacks and 773 subsequent losses reaffirmed the jaguar's right to live. Furthermore, people shared the same perception of procedural justice and perceived a clear distinction between the criteria of distributive justice, i.e. need and merit. Additionally, some of the criteria that were marginally

776 important, such as individual responsibility for jaguar survival and land-use rights, should not 777 be ignored as they might play an important role in people's frustration and in explaining 778 potential retaliation. Our results can inform practitioners of specific factors that can positively influence a 780 change in people's perception of the criteria affecting their sense of fairness. For example, 781 both the perceptions of frequency of attacks and of control over jaguar depredation influenced 
782

783

784

785

786

787

788

789

790

791

792

793

794

795

796

797

798

799

800

801

802

803

804

805

people's views that they should be able to act freely on their land. Current programmes to reduce livestock predation should be reinforced to discourage people to retaliate against jaguars on their land. Furthermore, cooperation with ranchers might be improved by acting on those factors that influence the perception of individual responsibility toward jaguar management. Programs that allow the development of a shared sense of responsibility toward the jaguar would increase people's individual sense of responsibility. Furthermore, in Calakmul, considering the Reserve's actions to be adequate was related with an increased sense of personal responsibility toward jaguar management. However, this was not the case if it was considered that the NGO or the government acted adequately; rather, this led to the unwanted result that people reduced their own sense of responsibility (see appendix 2). We believe this result shows the relevance of programs that directly involve communities, such as the temporary employment program of the Reserve, where a contract between the Reserve and local actors is established, leading local actors to feel responsible for their actions.

Organizations and institutions should better understand how local people perceive their actions to adopt management practices that support positive feelings of fairness. For example, consideration of local knowledge seemed more important if people perceived NGOs were responsible for jaguar management (it was far less important if they perceived that ejido authorities or individuals were responsible) (see appendix 2). This demonstrated that people felt their knowledge had been ignored in previous NGO interventions. Imposition of dominant conceptions of knowledge can increase people's feelings of injustice and decrease support for a particular organization (Coolsaet, 2016). On the other hand, people stressed that the Reserve should adopt a neutral approach. This might reflect concerns that managers do not listen to local actors, even when consulting them, because their minds are made up in advance and they only support a conservation agenda (Lauer et al., 2017; Smith and McDonough, 2001). It 
806 is important to consider those feelings of justice, since even minority groups can be vocal and

807 stimulate conflict around species conservation (Lute and Gore, 2014).

808

809

4.3. Approaches to fairness in environmental management

810 The novel and sophisticated quantitative approach we employed allowed us to demonstrate

811 the power of using criteria selection to achieve a nuanced understanding of how people build

812 their perceptions of justice. Using an enhanced version of the Bradley-Terry-Luce model, we

813 analyzed the plurality of justice perception and how it is influenced by different covariates.

814 The strength of this statistical analysis is that it can reveal complex patterns of perceptions of

815 fairness. Rather than assessing the dominant views of justice, our approach showed the

816 importance of the variability in people's description of fairness. In addition, it highlighted the

817 complexity of the criteria by which people construct their perception. Such statistical analysis

818 might not be applicable for every biodiversity conflict study, but acknowledging that this

819 complexity exists and the importance of identity and relationships are likely to be relevant to

820 other conflicts.

$821 \quad$ People have diverse views of justice and justify their positions using criteria from all

822 dimensions of justice. Importantly, success in addressing one dimension will not reduce the

823 potential impact of failure to comply with another dimension (Zafra-Calvo et al., 2017).

824 Moreover, results are highly context-specific, so criteria should be based on local people's

825 construction of justice. In addition, criteria can represent various points of view (e.g.

826 representation can be a desire to voice their concerns or a wish to participate directly through

827 voting; Smith and McDonough, 2001). This variability can add a layer of complexity in

828 interpreting and translating the results into action, making it necessary to accompany such an

829 approach with qualitative research allowing a deeper understanding of the situation. Whilst

830 results from this study offer important new insights, it is the combined knowledge from both 
our qualitative understanding of the situation (Lecuyer et al., 2018) and the quantitative results shown here that allow us to develop specific recommendations to support conservation efforts.

Our recommendations might help address particular feelings of justice and play a role in conservation success. It is clear that only addressing distributive aspects of justice, using schemes such as financial compensation for livestock losses, does not fully satisfy feelings of fairness and other aspects of fairness are considered to be more important for many people in counteracting biodiversity conflicts. We also agree with researchers who claim that there will be no single solution that will address everyone's feeling of justice (Jacobsen and Linnell, 2016; Martin et al., 2014; Müller, 2011). Still, the complexity of the feelings of justice should not prevent us from seeking routes toward enhancing fairness in environmental management. The importance of group relationships supports the need to develop collaborative approaches (Lauer et al., 2017; Sikor et al., 2014; Dawson et al., 2017). However, approaches that only aim to aggregate local actor preferences to legitimate specific and predetermined conservation goals will not be sufficient to acknowledge people's multiple perceptions of fairness (Durand et al., 2014). To agree on conservation practices that will appear just and fair to different actors, researchers and managers must engage in a difficult dialogue where local actors openly verbalize their notion of justice, acknowledge their differences, build mutual understanding and trust, and try to help groups of actors develop common identities (Durand et al., 2014; Müller, 2011). The value in having such diverse perceptions of justice is that it opens the door for extensive debate and collective reflection, thus developing relationships among actors, which we believe is itself a step toward more sustainable solutions for jaguar conservation, and indeed conservation more widely. 


\section{Acknowledgments}

857 This research would not have been possible without the kind support of numerous people in

858 Calakmul who shared their knowledge. We would like to thank Maria Manzon Che who 859 helped to interview, and Gunther Schauberger for direction on the best use of the BTLLasso 860 package. We are grateful to three anonymous reviewers and Dr. Roth for their useful 861 comments that contributed to improve the clarity of our manuscript. Funding was provided by 862 MITACS through a Globalink Research Award to MLL, BS and SC, a José-Sarukhan 863 Excellence Award given by the Centro del Cambio Global y Sustentabilidad del Sureste to 864 MLL, an Excellence Award from the Quebec Center for Biodiversity Science to MLL, and a 865 grant from the Université de Sherbrooke to SC.

866

867 References:

868 Agyeman, J., Schlosberg, D., Craven, L., Matthews, C., 2016. Trends and directions in 869 environmental justice: from inequity to everyday life, community, and just $870 \quad$ sustainabilities. Annu. Rev. Environ. Resour. 41.

871 Bradley, R., \& Terry, M., 1952. The Rank Analysis of Incomplete Block Designs 1: The 872 Method of Paired Comparisons. Biometrika, 39, 324-245. Bredin, Y.K., Lescureux, 873 N., Linnell, J.D., 2018. Local perceptions of jaguar conservation and environmental justice in Goiás, Matto Grosso and Roraima states (Brazil). Global Ecology and Conservation 13, e00369.

876 Calinski, T., Harabasz J.. 1974. A dendrite method for cluster analysis. Commun. Stat. 3, 1877 27.

878 Cattelan, M., 2012. Models for paired comparison data: A review with emphasis on dependent data. Stat. Sci. 412-433. 
Clayton, S., Kals, E., Feygina, I., 2016. Justice and Environmental Sustainability, in: Sabbagh, C., Schmitt, M. (Eds.), Handbook of Social Justice Theory and Research. Springer New York, pp. 369-386. https://doi.org/10.1007/978-1-4939-3216-0_20

Clayton, S.D., Opotow, S., 2003. Identity and the natural environment: The psychological significance of nature. Mit Press.

Coleman, J.S., 1958. Snowball sampling: problems and techniques of chain referral sampling. Human Organization 17, 28-36.

Colvin, R.M., Witt, G.B., Lacey, J., 2015. The social identity approach to understanding socio-political conflict in environmental and natural resources management. Glob. Environ. Change 34, 237-246.

Coolsaet, B., 2016. Towards an agroecology of knowledges: Recognition, cognitive justice and farmers' autonomy in France. J. Rural Stud. 47, 165-171.

Davenport, M.A., Leahy, J.E., Anderson, D.H., Jakes, P.J., 2007. Building trust in natural resource management within local communities: a case study of the Midewin National Tallgrass Prairie. Environ. Manage. 39, 353-368.

Dawson, N., Martin, A., Danielsen, F., 2017. Assessing equity in protected area governance: Approaches to promote just and effective conservation. Conserv. Lett.

Della Fave, L.R., 1986. Toward an explication of the legitimation process. Soc. Forces 65, 476-500.

Hegtvedt, K.A., Clay-Warner, J., Johnson, C., 2003. The social context of responses to injustice: Considering the indirect and direct effects of group-level factors. Soc. Justice Res. 16, 343-366.

INEGI (2015) “Encuesta Intercensal 2015”, http://www.beta.inegi.org.mx/proyectos/enchogares/especiales/intercensal/ (accessed May 2016). 
Inskip, C., Zimmermann, A., 2009. Human-felid conflict: a review of patterns and priorities worldwide. Oryx 43, 18-34.

Jacobsen, K.S., Linnell, J.D., 2016. Perceptions of environmental justice and the conflict surrounding large carnivore management in Norway_-Implications for conflict management. Biol. Conserv. 203, 197-206.

Kals, E., Russell, Y., 2001. Individual conceptions of justice and their potential for explaining proenvironmental decision making. Soc. Justice Res. 14, 367-385.

Kellerhals, J., Coenen-Huther, J., Modak, M., 1988. Figures de l'équité: la construction des normes de justice dans les groupes., Presses universitaires de France. ed.

Kellerhals, J., Modak, M., Perrenoud, D., 1997. Le sentiment de justice dans les relations sociales, Presses universtaires de France. ed.

Lauber, T.B., 1999. Measuring fairness in citizen participation: a case study of moose management. Soc. Nat. Resour. 12, 19-37.

Lauer, F.I., Metcalf, A.L., Metcalf, E.C., Mohr, J.J., 2017. Public Engagement in SocialEcological Systems Management: An Application of Social Justice Theory. Soc. Nat. Resour. 1-17.

Lecuyer, L., White, R.M., Schmook, B., Lemay, V., Calmé, S., 2018. The construction of feelings of justice in environmental management: An empirical study of multiple biodiversity conflicts in Calakmul, Mexico. Journal of Environmental Management 213, 363-373.

Legendre, P., Legendre, L., 2012. Numerical Ecology, Third Engl. ed. Elsevier Science B.V, Great Britain

Lind, E.A., Tyler, T.R., 1988. The social psychology of procedural justice. Springer Science \& Business Media. 
Lute, M.L., Gore, M.L., 2014. Stewardship as a path to cooperation? Exploring the role of identity in intergroup conflict among Michigan wolf stakeholders. Hum. Dimens. Wildl. 19, 267-279.

Marques, S., Lima, M.L., Moreira, S., Reis, J., 2015. Local identity as an amplifier: Procedural justice, local identity and attitudes towards new dam projects. J. Environ. Psychol. 44, 63-73.

Martin, A., Coolsaet, B., Corbera, E., Dawson, N.M., Fraser, J.A., Lehmann, I., Rodriguez, I., 2016. Justice and conservation: The need to incorporate recognition. Biol. Conserv. $197,254-261$.

Martin, A., Gross-Camp, N., Kebede, B., McGuire, S., Munyarukaza, J., 2014. Whose environmental justice? Exploring local and global perspectives in a payments for ecosystem services scheme in Rwanda. Geoforum 54, 167-177.

Müller, M.M., 2011. Justice as a framework for the solution of environmental conflicts, in: Justice and Conflicts. Springer, pp. 239-250.

Ohl, C., Stickler, T., Lexer, W., Beckenkamp, M., Risnoveanu, G., Geamana, N., Fischer, A., Fiorini, S., Dumortier, M., Casaer, J., 2008. Governing biodiversity: procedural and distributional fairness in complex social dilemmas, in: The 12th Biennial Conference of the International Association for the Study of Commons, 14-18 July 2008. p. 31.

Oksanen, J., Blanchet, F.G., Kindt, R., Oksanen, M.J., Suggests, M., 2015. Vegan: Community Ecology Package. R Package Version 2.5-2., 0-0.

Oldekop, J.A., Holmes, G., Harris, W.E., Evans, K.L., 2016. A global assessment of the social and conservation outcomes of protected areas. Conserv. Biol. 30, 133-141.

Parris, C.L., Hegtvedt, K.A., Watson, L.A., Johnson, C., 2014. Justice for all? Factors affecting perceptions of environmental and ecological injustice. Soc. Justice Res. 27, $67-98$. 
954 Redpath, S.M., Young, J., Evely, A., Adams, W.M., Sutherland, W.J., Whitehouse, A., Amar,

955

956

957

958

959

960

961

962

963

964

965

966

967

968

969

970

971

972

973

974

975

976

977

A., Lambert, R.A., Linnell, J.D., Watt, A., 2013. Understanding and managing conservation conflicts. Trends Ecol. Evol. 28, 100-109.

Rodríguez-Soto, C., Monroy-Vilchis, O., Maiorano, L., Boitani, L., Faller, J.C., Briones, M.Á., Núñez, R., Rosas-Rosas, O., Ceballos, G., Falcucci, A., 2011. Predicting potential distribution of the jaguar (Panthera onca) in Mexico: identification of priority areas for conservation. Divers. Distrib. 17, 350-361.

Sanderson, E.W., Redford, K.H., Chetkiewicz, C.-L.B., Medellin, R.A., Rabinowitz, A.R., Robinson, J.G., Taber, A.B., 2002. Planning to save a species: the jaguar as a model. Conserv. Biol. 16, 58-72.

Schauberger, G., Tutz, G., 2017. BTLLasso-A Common Framework and Software Package for the Inclusion and Selection of Covariates in Bradley-Terry Models.

Schlosberg, D., 2007. Defining Environmental Justice. Oxford: Oxford University Press.

Schmook, B., Radel, C., 2008. International labor migration from a tropical development frontier: Globalizing households and an incipient forest transition. Hum. Ecol. 36, $891-908$.

Semarnat (Secretaría de Medio Ambiente y Recursos Naturales). 2010. Norma Oficial Mexicana NOM-059-SEMARNAT- 2010, Protección ambiental -especies nativas de México de flora y fauna silvestres - Categorías de riesgo y especificaciones para su inclusión, exclusión o cambio - Lista de especies en riesgo. Diario Oficial de la Federación. 30 de diciembre de 2010, Segunda Sección. México. 12 de julio de 2012: $1-35$

Sikor, T., Martin, A., Fisher, J., He, J., 2014. Toward an empirical analysis of justice in ecosystem governance. Conserv. Lett. 7, 524-532. 
Skitka, L.J., Aramovich, N.P., Lytle, B.L., Sargis, E.G., 2010. Knitting together an elephant: An integrative approach to understanding the psychology of justice reasoning, in: The Psychology of Justice and Legitimacy: The Ontario Symposium. pp. 1-26.

Smith, P.D., McDonough, M.H., 2001. Beyond public participation: Fairness in natural resource decision making. Soc. Nat. Resour. 14, 239-249.

Stets, J.E., Biga, C.F., 2003. Bringing identity theory into environmental sociology. Sociol. Theory $21,398-423$.

Treves, A., and Karanth, K.U., 2003. Human-carnivore conflict and perspectives on carnivore management worldwide. Conserv. Biol. 17, 1491-1499.

Turner, B.L., Geoghegan, J., Foster, D.R., 2004. Integrated land-change science and tropical deforestation in the southern Yucatán: Final frontiers. Oxford University Press on Demand.

Utne, M.K., Kidd, R.F., 1980. Equity and attribution. Justice Soc. Interact. 63-93.

Warman, A., Warman, A., 2001. El campo mexicano en el siglo XX.

White, R.M., Fischer, A., Marshall, K., Travis, J.M., Webb, T.J., Di Falco, S., Redpath, S.M., 1353 and van der Wal, R., 2009. Developing an integrated conceptual framework to understand 1354 biodiversity conflicts. Land Use Policy 26, 242-253.

Zafra-Calvo, N., Pascual, U., Brockington, D., Coolsaet, B., Cortes-Vazquez, J.A., GrossCamp, N., Palomo, I., Burgess, N.D., 2017. Towards an indicator system to assess equitable management in protected areas. Biol. Conserv. 211, 134-141.

Zarco-González, M.M., Monroy-Vilchis, O., Alaníz, J., 2013. Spatial model of livestock predation by jaguar and puma in Mexico: Conservation planning. Biol. Conserv. 159, $80-87$. 